\title{
短期記憶の保持時間内における位置の想起の精度
}

\author{
正会員 宮 里 勉 ${ }^{\dagger}$

\section{Accuracy Evaluation on Positions Recalled from Short-Term Memory}

\author{
Tsutomu Miyasato ${ }^{\dagger}$
}

\begin{abstract}
Experimental results are reported for how people accurately recall the location of a point from their short-term memory.

People identify a specified picture by using key words on the objects in pictures and the spatial relationships of those objects to distinguish one picture from another. The layout information in pictures can be used to retrieve them from a database.

However, the layout information given by people is often vague. Therefore, the wider the search area, the longer the retrieval process. On the other hand, the narrower the search area, the greater the risk of missing the target picture.

This study evaluates the accuracy of recalling locations in a picture within the time-span of short-term memory. It is found that the true position is estimated based on an area that represents only $5 \%$ of the picture and which is centered on the position specified.
\end{abstract}

\section{1. ま え がき}

本稿は, 位置の記憶における人間の精度に関する実 験の報告である。想起される位置の正確さは, 検索者 が想起した画像内の物体のレイアウト情報を用いる画 像検索において, 検索の効率に影響する重要な要因で ある。すなわち，指定された位置と一致したと判断す る範囲の大小は, 検索時間の長短および検索の成否に 影響する。

画像の検索では，文字デー夕を対象とする検索とは
異なり, 利用者の意図する画像に対する, 文字だけで は表現しにくい情報が重要な検索条件となる，そこ で, 従来から要素画像の画像内での「位置」,「姿勢」, 「大きさ」,「形」や要素画像間の相対的な位置関係を利 用したレイアウトによる検索が検討されている ${ }^{1) ~ 3)}$. それらのレイアウト情報を用いる画像検索では「一度 見たことのある画像について思い浮かべるとき, 画像 の中に存在していた物体などを, それがあった位置に 配置するように頭の中に思い描く」という経験に基づ いている4).また，検索に関わる想起に関連しては,

キーワード : 短期記憶, 位置の想起, レイアウト情報, 画像検索, 要素画像, ユーザインタフェース

$\dagger \mathrm{KDD}$ 研究所 ( $₹ 356$ 上福岡市大原 2-1-15, TEL 0492-66-7400)

$\dagger$ KDD R \& D Laboratories (2-1-15, Ohara, Kamifukuoka-shi, Saitama 356, Japan)

* 現在, ATR 通信システム研究所 (广 619-02 京都府相楽都精華町光台 2-2, TEL. 07749-5-1277)

ATR Communication Systems Research Laboratories (2-2 Hikaridai, Seika-cho, Soraku-gun, Kyoto 619-02, Japan) 


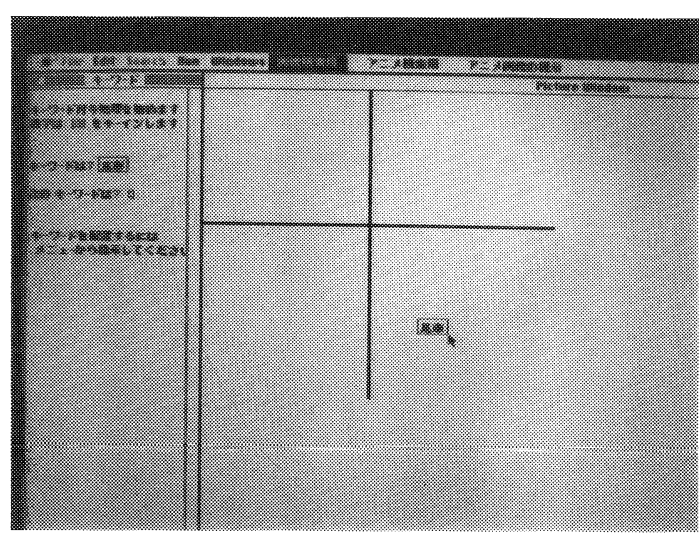

(a)

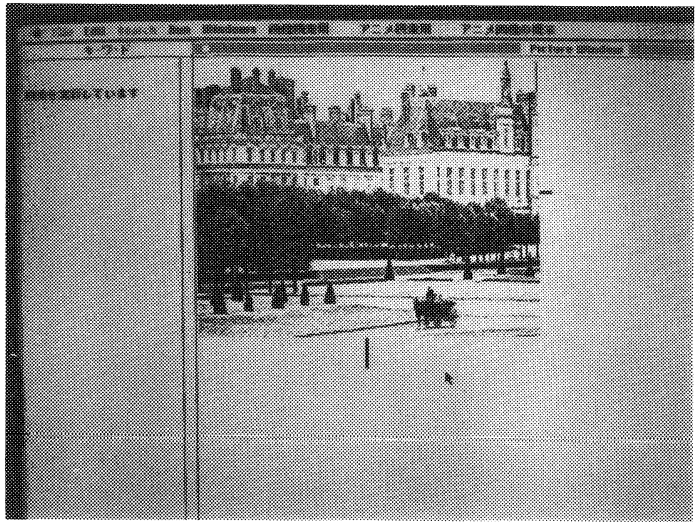

(b)

写真 1 キーワードのレイアウトによる検索の例

Example of image retrieval depending layout of key words.

人が新聞等の一度読んだことのある記事を再検索する 場合，「紙面上の位置」の記憶が重要な手掛かりのひ とつであることが報告されている5.

レイアウト情報を用いる画像検索は, 画像の構図の 情報も検索者が指定できるので，単にキーワードを並 べて検索するよりも人間を相手に検索の要求を出す形 態に近いという意味で，自然なユーザインタフェース である．また，同じキーワードでも画像の右側にあっ たものか左にあったかを指定できるので，検索候補の 絞り込みも速まる。

レイアウト情報を用いる場合, 検索用の端末の画面 モニタをキャンパスと見立てて，キャンパス内に配置 されている車や人などの特定の複数の対象物の位置を 指定する.

ところで，レイアウト情報を用いる検索において は，検索者が目的としている画像がうまく検索される か否かは，検索者が想起した位置の情報が正確である ことが前提にある。

しかし，検索者の想起した情報には曖昧性が伴う。 検索者が指定した位置を全く信用すれば，検索の範囲 が狭まり検索時間が短縮されるが，目的の画像が検索 から漏れる危険率は非常に高くなる，逆に，検索者が 指定した位置を全く無視すれば，レイアウト情報を用 いる利点がなくなる。

したがって, システム側でデフォルトの存在範囲を 用意しておく必要があり，位置の記憶における人間の 精度に関して検討することは，最適な検索範囲を設定 する上で重要である.

従来，レイアウト情報を用いる検索では，検索者が 想起した位置の正確さに関しての充分な検討がなされ ていない。そこで, 人間の記憶・想起の特性について
調べることにした．ただし，絵画や風景を人間が記憶 する際には，その人にとって何らかのインパクトがあ るものがより長く記憶に残るように，記憶の保持の強 さが個人の興味の方向と度合いの影響を受けやすいと いうことを考慮しなければならない。

本稿では，画像内のレイアウト情報を用いる検索作 業に関わる人間の特性を調べる予備的な実験として, 興味の方向と度合いの個人差が関わる前の, 短期記憶 の記憶保持時間内での想起の精度について測定した。

\section{2. 想起される位置の精度と位置の検索範囲}

筆者らは, 画像デー夕の検索を目的として, 文字に よる画像内容の抽象化表現に加えて画像内の要素とな る部分画像 (以下, 要素画像と呼ぶ) の位置の情報を用 いる画像検索システムを検討している ${ }^{6)}$.

この画像検索システムでは, 要素画像を成す対象物 の特定にはキーワードによる文字言語記述と指定を行 い, 要素画像の位置およびそれらの位置関係の記述に は，その要素画像を指定するキーワードの文字自体を マウスで画面上に配置する．写真 1 は，4 つの象限に 分けた画像枠の第 4 象限に馬車が写っている画像を検 索する様子を示している，写真 1 (a)では，検索者は キーワードの「馬車」という文字枠をマウスで画像枠 の第 4 象限内に配置している. 写真 1 (b) は, 検索さ れた結果の画像である。

表 1 は, 53 枚の画像を使って 1 人の被験者が記憶・ 想起した際の, 全体で 149 個の要素画像の配置におけ る実際の象限を被験者が詔って指定した象限の割合の 例である。

表 1 の例では, 画像枠の単純な 4 分割では, 領域の 境界付近でのわずかな位置のずれが領域の違いに影響 
表 1 画面の 4 象限分割における記憶している象限間 の混同率

Confusion matrix among four areas where objects are recalled.

\begin{tabular}{c|c|c|c|c}
\hline \hline \multirow{2}{*}{ DB 内象限 } & \multicolumn{2}{|l}{ 被験者指定象限 } & & \\
\hline I & I & II & III & IV \\
\hline II & $32.0 \%$ & $32.0 \%$ & $12.0 \%$ & $24.0 \%$ \\
\hline III & $29.6 \%$ & $38.9 \%$ & $18.5 \%$ & $13.0 \%$ \\
\hline IV & $11.5 \%$ & $14.2 \%$ & $45.7 \%$ & $28.6 \%$ \\
\hline
\end{tabular}

を及ぼし，想起に基づく領域と実際の領域との一致が 低くなったと思われる。 また, 被験者の内観報告によ ると，領域の境付近では選択に迷うとのことであった．

そこで，画像条件をあらかじめ幾つかの領域に仮想 的に分割しておく場合，細分化すると領域の選択誤差 による位置の検索対象領域の増大化を抑えることがで きる，また，検索者が指定する位置に対して適宜に位 置の検索対象領域を設定することもできる，そのた め, 想起される位置に対して, システム側でデフォル トの検索範囲を設定しておく必要がある。

\section{3. 想起される位置の精度の測定実験}

本実験は，蓄積されている画像を構成している物体 などの要素画像の位置と検索者が指定した位置との比 較をする際に，一致したと判断する範囲をどの程度に 設定するかの基準を得ることを最終的な目的としてい る.

絵画や風景を人間が記憶する際には，その人にとつ て何らかのインパクトがあるものが，より長く記憶に 残る。そこで今回の実験では，人によって異なる興味 の方向と度合いに左右されずに位置の想起の精度を測 定することにして，点を記憶の対象にした短期記憶の 記憶保持時間内での想起の精度を測定した．

測定は，画像を構成している要素画像の配置を言葉 で指示する際の重要な要因7) 参考に, 表示サイズ, ディスプレイ内での対象物体の位置に注目して, 以下 の 3 つの実験を行った.

（1） 1 個の点の位置の記憶・想起における再現誤 差の測定.

（2）実験(1）に対する点の表示領域の影響の有無 の測定

（3）実験 (1) に対する記憶用と想起用の画面サイ ズの影響の有無の測定.

表 2 に, 4 章で述べる 3 種類の実験に共通する実験
表 2 実験環境および実験条件

Parameters and conditions in experiment.

(a) 実験環境

\begin{tabular}{c|l}
\hline \hline 装 置 & Macintosh II \\
\hline モニタ & $\begin{array}{l}\text { 16インチカラーCRT ディスプレイを白黒モ } \\
\text {-ドで使用 } \\
\text { (横 } 1016 \times \text { 縦 } 767 \text { 画素が使用可) }\end{array}$ \\
\hline 照明 & オフィス照明, モニタの輝度は被験者が調整 \\
\hline 視距離 & $40 〜 50 \mathrm{~cm}$ (非固定で, 被験者の自由設定) \\
\hline
\end{tabular}

(b) 実験条件

\begin{tabular}{|c|c|}
\hline 画像枠の形状 & 正方形 \\
\hline 画像枠のサイズ & $\begin{array}{l}\text { ・実験 } 1 \text { と } 2 \text { では, 記憶用と想起 } \\
\text { 用の画像枠は同サイズ }(500 \times 500 \\
\text { 画素 }) \\
\text { • 実験 } 3 \text { では, 記憶用と想起用の } \\
\text { 画像枠のサイズを面積比で, } 1 / \\
7 \sim 7 / 1 \text { の } 7 \text { 種類 }\end{array}$ \\
\hline 記憶する対象 & 1 点 (2 画素幅) \\
\hline 記憶のための呈示時間 & 5 秒 \\
\hline マスキングの時間 & 2 秒 \\
\hline 背景画像 & 白地 \\
\hline 記憶用画像枠の表示位置 & ディスプレイの中央 \\
\hline 想起用画像枠の表示位置 & ディスプレイ内でランダムな位置 \\
\hline
\end{tabular}

環境と実験条件を示す。なお，記憶のための呈示時間 の長さの 5 秒は, 予備実験を行って経験的に決定し た。すなわち，1個の点の位置の検索・確認の時間に は 5 秒あれば目標点の見逃しはなかったこと,また， 呈示時間を 5 秒より長くした場合には被験者の集中力 の低下が見受けられ, 記憶課題に対して逆効果になる と思われたことによる。また，短期記憶の記憶保持時 間の長さとしては 2 秒間に設定した。それは, 視覚的

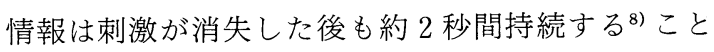
や, 短期記憶の保持時間は数秒 $(4 \sim 10 \text { 秒程度 })^{9)}$ とい われていることに基づいている。ささに, Sternberg による文字の知覚像と記憶像との照合過程の実験 ${ }^{10)}$ におけるターゲット呈示間隔が 2 秒であることも参考 にした

\section{1 実験手順}

測定を始める前に, 被験者に課題を示して充分な練 習を行った。なお，被験者は 20 代と 30 代の 6 名で, 1 人ずつ個別に実験した。課題は 50 個の点について 行い, 全体時間は約 3 分毎の休息を含めて約 15 分で ある。

図1に被験者の行う課題の流れを示す。

(79) 1125 


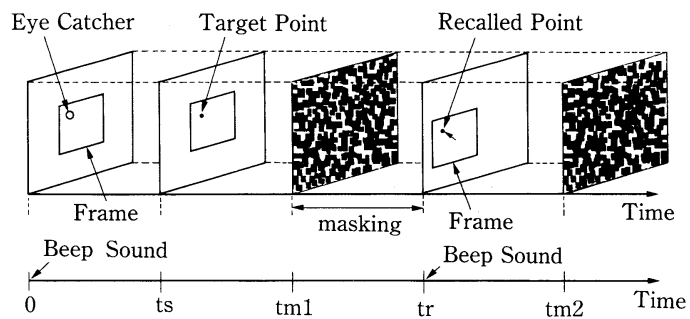

図 1 課題の流れ

Sequence of evaluation test.

（1）まず，ディスプレイの中央に画像枠を表示 し, 画像枠内のランダムな位置に 1 個の点を呈 示して, 被験者にその点の位置を記憶させる. [0 $\mathrm{tm} 1]$

ただし，呈示した点を見失わないように，夕 ーゲットを中心としてアイキャッチ用の円をフ ラッシュ表示する。また，同時にビープ音を与 える。

（2） 5 秒間の点の呈示の後, 想起・再生のための 画像枠の表示の前に, 残像の消去と記憶の曖昧 化を目的として 2 秒間のランダムドットの画像 の表示を行う。ラムダムドット画像が消える と，ビープ音とともに想起用の画像枠を表示す る. $[\mathrm{tm} 1 \sim \mathrm{tr}]$

（3）その後，記憶の時の画像枠と同じサイズの画 像枠がディスプレイ内のランダムな位置に表示 され，被験者は想起した点の位置をマウスで指 定する。ただし，指定までの時間の長さは制限 しない. $[\mathrm{tr} \sim \mathrm{tm} 2]$

被験者がマウスをクリックして位置を確定す ると，画像枠はディスプレイから消える。

[tm 2]

以上の記憶・想起の作業を, 1 被験者につき 50 回繰 り返す。

\section{2 実験内容}

以下に 3 種類の実験を順に述べる。

（1）実験 $1 ： 1$ 個の点の記憶・想起における再現 精度

この実験では，一定のサイズの画面内のランダムな 位置に一定時間 1 点を表示して, 被験者にその点の位 置を記憶させた．次に，最初の画面と同じサイズの画 面をランダムな位置に呈示して, 被験者が想起した点 の位置をマウスで指定させた 。

目的は, 1 点のランダム配置における, 呈示位置と 被験者が記憶・想起した位置との座標差分の平均值と

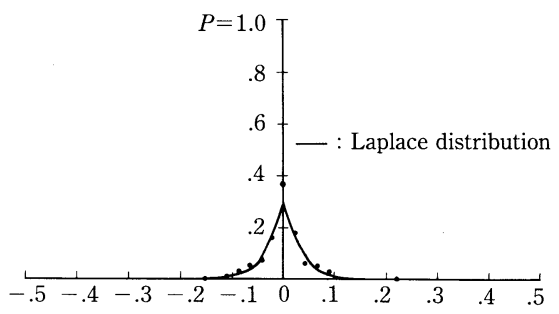

(a)
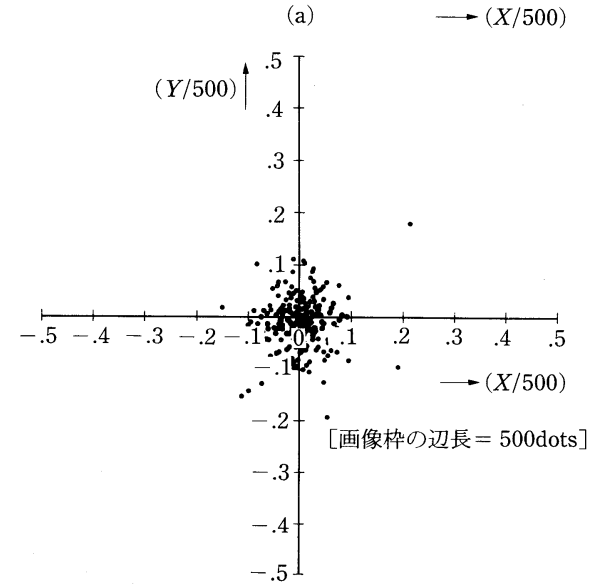

(b)

図 2 課題位置と被験者が想起した位置との座標差分 （画像枠の辺長 $=500$ dots）

Position error of recalled points and approximation by Laplace distribution.

分散值を測定することである。

以下に実験結果を述べる。図 2 は，500 個の点の位 置についての課題位置と被験者が想起した位置とのず れの様子を示したものである。ただし，ディスプレイ 画像枠の一辺の長さで正規化している。また座標の差 の確率分布は, 平均值は 0 （有意水準 $\alpha=0.05 ）$, 標準 偏差值 $\sigma$ は $500 \times 500$ ドットの正方画像枠の 1 辺の長 さの約 $5 \%$ である.

図 2(a)からわかるように, 分布の形状はラプラス 分布またはガウス分布に近い単峰形をしている。そこ で，分布のモデル化としてラプラスまたはガウス分布 での近似が考えられるが，適合度の $x^{2}$ 検定の結果は いずれの分布も棄却された。（有意水準 $\alpha=0.05 ）$

（2）実験 2：1 個の点の位置の記憶に対する表示 画像枠内での領域の影響

実験 1 の 1 個の点の記憶・想起における再現精度の 実験において，被験者から，画像枠の近くでは位置を 記憶しやすいとの感想があった。したがって，画像枠 内の領域によって検索者の位置の記憶精度が影響を受 ける可能性がある.

そこで，画像枠内の領域により分布に相違が見られ 

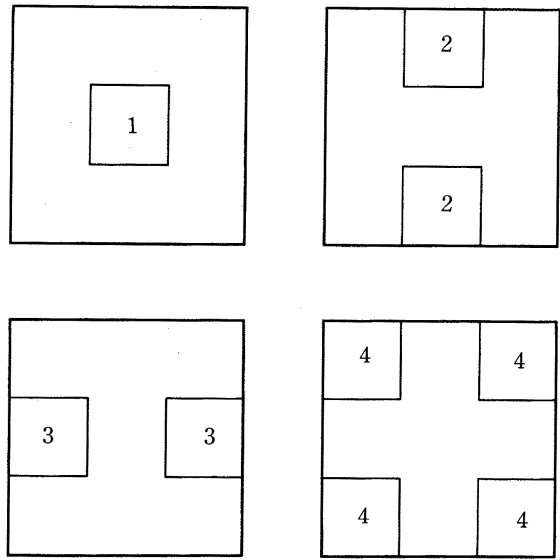

図 3 表示位置の影響を調べるために仮想的に分割し た画像枠の 4 領域

Picture frame virtually divided into four areas to check spacial effect to easiness of memorization.

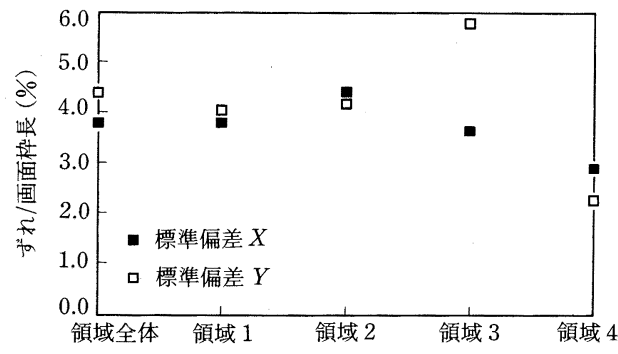

図 4 画像枠内の 4 領域での位置ずれの標準偏差 Comparison of standard deviations of position error of four areas in a picture frame.

るかを調べた，実験方法は実験 1 の場合と同じである が，記憶用の点を呈示する際に図 3 に示すように， (1) 画像枠の中心部, (2) 上下の境界付近, (3) 左右 の境界付近，（4）4 頂角付近，の4 領域に区分し，領 域毎に均等に課題の点の位置を表示するようにした． ただし，被験者は領域について知らされていない。

図 4 に, 位置ずれの標準偏差值を画像枠の長さの比 で示す．画像枠上下の境界付近（領域 2) では， $X$ 軸 の分散が $Y$ 軸の分散より大きく, 一方, 画像枠の左 右の境界付近の領域（領域 3) では， $Y$ 軸の分散が $X$ 軸の分散より大きい.したがって, 記憶用の点の表示 領域によって垂直方向と水平方向とで位置の記憶度に 差が見られる。

画像枠の中心部（領域 1) では, $X$ 軸および $Y$ 軸の 分散が領域 3 と領域 4 の小さい方の分散值に近い結果 となっている.

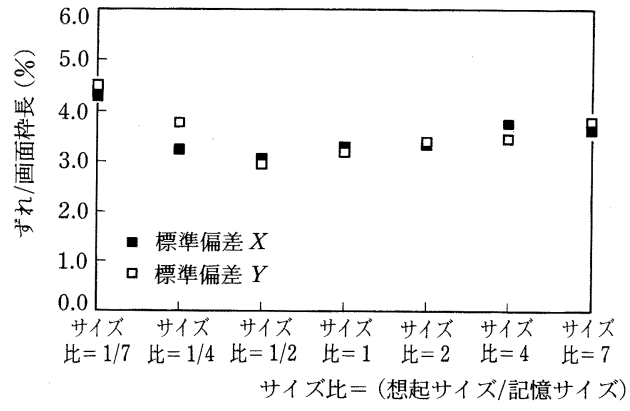

図 5 記憶用と想起用の画像枠サイズが異なる場合の 位置ずれの標準偏差

Standard deviations of position error when picture frame for recalling isn't equal to picture frame used for memorization.

また, 画像枠の頂点近くの領域（領域 4）で, $X$ 軸 および $Y$ 軸の分散が他の領域での分散より小さい.

なお，位置ずれの標準偏差の值は，画像枠の長さに 対して, 最小で $2 \%$, 最大でも $6 \%$ 以下, 全体の領域 では約 4\%である。

（3）実験 $3 ： 1$ 個の点の位置の記憶に対する記憶 用と想起用の画像枠サイズの違いの 影響

検索者が画像枠内での要素画像の位置を指定する画 像検索の方法に扔いて，画像枠のサイズによる影響が 考えられる。

例えば，八ガキ大のサイズの画像を見た後，検索シ ステムを使って，その画像を検索する場合を想定す る.この場合, 検索用の端末モニ夕画面のサイズが 16 インチだとすると, 画像枠の相似比率が画像枠内 の位置の記憶度に影響すると考えられる。

画像枠の相似比率の影響が大きいと, 検索者が指定 した位置の曖昧度が大きくなり，画面全体を調べるこ とにもなりかねない。なぜならば，検索者が意図して いる実際の画像のサイズは不明であるし，たとえ検索 者が画像のサイズを入力したとしても，そのサイズの 情報自体の曖昧度も考慮しなければならないからであ る。

そこで，画像枠の相似比率によって検索者の位置の 記憶度が影響を受けるか否か, 影響があるとするとそ の程度を明らかにするために測定を行った。

実験の基本環境は実験 1 の 1 個の点の記憶・想起に おける再現精度の場合と同じであるが，新たに記憶用 と想起用の画面面積のサイズ比を違えた．実験に用い た画像枠のサイズ比は，記憶用対想起用の画像枠の面 積比で, $1 / 7,1 / 4,1 / 2,1 / 1,2 / 1,4 / 1,7 / 1$ の 7 種 類である。 
図 5 は, 記憶用と想起用との画像枠サイズが異なる 場合の, 各サイズ比における標準偏差の比較である.

記憶用と想起用の画像枠のサイズが異なる場合, 記 憶している画面サイズに対して想起用の画面サイズが 小さくなるにつれて, 位置の記憶のずれが増大する傾 向が見られる.

また, 各サイズ比において, 想起した位置のずれの 標準偏差は画像枠の 1 辺の長さの 3 5\%の範囲であ る。

\section{4. 考察}

実験 1 の記憶用と想起用の画像枠サイズが等しい場 合, 想起した位置の $X$ 軸および $Y$ 軸の座標でのずれ の分布は, 平均值は 0 , 標準偏差值は画像枠の 1 辺の 長さの約 $5 \%$ あるる。また，ずれの分布の全体の約 99\%を含むずれの值を求めると 55 ドットになる.

したがって, 真の点の位置の存在範囲は, 検索者が 指定した位置を中心として， $X$ 軸および $Y$ 軸の正負 の方向に 55 ドットの距離以内になり, 面積で表すと 一辺の長さが 500 ドットの画像枠の面積の約 $5 \%$ の範 囲に相当する.

実験 2 の 1 個の点の位置の記憶に対する表示画像枠 内での領域の影響の有無については, 画像枠内での記 憶用の点の表示領域によって, 垂直方向と水平方向と で位置の記憶度に差が見られた。すなわち画像枠の上 下の水平境界近くの領域と画像枠の左右の垂直境界近 くの領域とで $X, Y$ 軸のずれの分散值の大小関係の逆 転がある。

この理由は, 被験者が点の位置を記憶する際に画像 枠の周辺の境界を基準にしているためと思われる。そ のため, 画像枠の垂直の境界を基準にできる左右の境 界付近では， $X$ 軸方向のずれの分散は小さくなるが, 上下の枠の境界を基準に取りにくい $Y$ 軸方向はずれ の分散が増大するものと思われる。

同様に，画像枠の上下の境界付近では，左右の枠の 境界を基準に取りにくい $X$ 軸方向のずれの分散が増 加するものと思われる。

一方, 位置の基準を画像枠の中心点に取れる画像枠 の中心付近执よび画像枠の頂角を基準点に取れる頂角 付近の領域では， $X$ 軸方向および $Y$ 軸方向ともにず れの分散が相対的に減少するものと思われる。

以上の $Y$ 軸の分散と $X$ 軸の分散との差に関連し て, 垂直・水平錯視現象での説明が考えられる. 垂 直・水平錯視現象では, 水平方向と垂直方向との間の 感度の相違により, 同一の長さの縦線と横線でも, 縦 線は横線よりも長く見える傾向にある ${ }^{11}$.
しかし, 垂直・水平錯視現象だけでは, 領域 3 にお ける $Y$ 軸の分散と $X$ 軸の分散との差が領域 2 の場合 よりも顕著となる理由づけはできても, 領域 3 と領域 4 での $Y$ 軸の分散と $X$ 軸の分散との大小の逆転が説 明できない。したがって， $Y$ 軸の分散と $X$ 軸の分散 の大小の差の説明に関しては, 今後さらに詳しい測定 が必要である.

以上, 表示領域の違いによる想起の位置ずれの標準 偏差は, 画面枠の長さの $2 \sim 6 \%$ の範囲に収まってお り, 領域全体では約 $4 \%$ である。ここで, 被検者が指 定した位置を中心として設定する検索範囲を考える と, 図 2(a)のような分布からは, 領域全体の場合の 標準偏差で置き換えたとしても，それより大きい偏差 值を持つ領域での真の位置が検索範囲内に存在する確 率の減少はわずかである。また，実際の偏差値が領域 全体の場合よりも小さい場合には，逆に真の位置が検 索範囲内に存在する確率が増す。

したがって, 表示領域の影響については, 検索者が 指定した位置毎に検索の対象範囲を変化させなくて も，領域全体から求めた想起の位置ずれの標準偏差を 用いてよいと思われる。

実験 3 は, 人間の認知機能における拡大縮小の操作 上での曖昧性の付加の影響を考慮したものであるが, 被験者はサイズの変化に対応して想起する位置の調整 をしていることを示している．

実験 1 ～3の全体を通しては, 想起自体の精度以外 に，再現精度に影響する他の要因が考えられる。すな わち, マウス操作の不確かさに起因するものであり, 腕の動作特性の影響とポインティング動作中の視線の 移動の影響である。

腕の動作特性の影響に関しては, 被験者が意図した 位置に正確にマウスを止めることができないというこ とである.今回の害験では, 呈示した点の位置の記憶 から想起するまでの時間は統制しているが, 被験者が 想起した位置をマウスで指定するのに要する時間は制 限していない。そのため被験者は，位置を確定するま で調整を繰り返してょいので, マウスの操作速度を意 識することなく楽な速度で作業すると思われる，点の ターゲットを表示したままでのポインティング精度の 測定の結果では, ポインティングのずれの標準偏差は 1.5 ドット以下と全体の標準偏差の 15 分の 1 の大き さである。したがって, マウス操作の不確かさにおけ る腕の動作特性の影響は無視できると思われる。

一方, ポインティング動作中の視線の移動の影響に 関しては, いったん点の位置を想起した後にカーソル をその位置に移動させる間に, 想起した位置が曖昧に 
なる恐れがある，すなわち，マウスを使用する場合に は, まずカーソルを探した後にカーソルを目標位置に 向けて動かす場合が多い.また，カーソルの移動中に も目標位置とカーソルとの間での視線の行き来が起こ るので, その間に想起した点の位置が暧昧になってい くことが考えられる。しかしながら, 今回の実験では 視線移動の影響について測定できていない.

マウス操作における視線移動とマウスの動きの運動 様式については測定がなされており, 文献 12)では, マウス操作の経験がない初心者による実験において, 視線が目標とマウスの間を行き来する運動様式は発生 頻度が非常に低いことが報告されている。また文献 13)では，マウス操作の習熟者を被験者として，マウ ス操作での手の 2 相の動作特性と眼球運動との関係を 検討しており，眼球を動かさずとも周辺視でマウスが 制御されることを明らかにしている. 今回の実験条件 である視距離約 $50 \mathrm{~cm}$, 画像枠の辺長約 $17 \mathrm{~cm}$ と比較 すると, 文献 12)ではカーソルの最大移動距離が視角 からの換算で約 $8 \mathrm{~cm}$ と短いので直接の対応は難しい が, 文献 13)ではカーソルの最大移動距離が $15 \mathrm{~cm}$ と 実験条件が似通っており, マウス操作に慣れた者を被 験者としていることも同じである。したがって, ボイ ンティング動作中の視線の移動は少なく, 想起した位 置の指定の際の誤差の影響は小さいものと考えられ る.

ところで文献 14)では, マウスによるポインティン グ操作に, 視線によるカーソル表示位置判定機能を組 合せたポインティング手法が提案されている.この手 法では, 被験者の注視している位置を検出して視点位 置にカーソルを発生させ, 微調整用にはマウス操作で カーソルを目標に移動する。したがって, 視線を併用 した場合には, 常に注視点の近くにカーソルが表示さ れるので, 被験者はカーソルを探すことなく指示動作 を行うことができる。

したがって, 目標位置とカーソルとの間での視線の 往復を減らしてカーソル操作による実験誤差の混入を 厳しく抑えるには, 視線検出を併用したマウスポイン ティング方式の使用が有効と思われる。 また今回は点 の位置の想起に関する測定であったが, 今後の想起す る目標物が大きさを持っている場合の実験では, タッ チパネルの使用によりポインティングエラー率の影響 と視線移動の影響を抑えることも可能と思われる。

ところで, 今回の測定結果を心理測定の観点から考 察すると, 刺激と弁別閾に関するウェーバの法則との 関連が考えられる。すなおち位置ずれの標準偏差値を 刺激における弁別閾として $\Delta S$ で表し，また点位置の
想起再現用の画像枠の一辺の長さを $S$ とすると, 記 憶用と想起用の画像枠の間の 7 種の面積比において, $\Delta S / S \simeq 5 \%$ とほほ一定である. 原著が入手できない ので不確かだが, 線分の長さに関するウェーバ比は $1 / 30^{15)}$ あるいは約 $1 / 100^{16)}$ とのことである. 弁別閥 $\Delta S$ に標準偏差值を用いるか, あるいは重み付けする かなどの弁別閾の定義により值は異なるが, 今回の測 定結果の $\Delta S / S \simeq 5 / 100$ は前述の值に近いものである. ただし，位置を記憶する時点の刺激自体にすでにウェ 一バ比の範囲で曖昧さを伴っているのか, それとも想 起する際に曖昧になるのかについてはわからない.

以上, 実験 1 から実験 3 までの結果から，2 秒間の 短期記憶保持時間内において, 想起した位置のずれの 分布は, 真の位置を中心として標準偏差が画像枠の 1 辺の長さの約 $5 \%$ としてよと思われる。

\section{5.むすび}

画面内で想起される点の位置の精度を短期記憶の保 持時間内で測定し, 以下の結果を得た.

（1）被験者が想起した点の位置は真の位置からず れており, 座標の差の分布は平均值 0 で標準偏 差 $\sigma$ は画像枠の 1 辺の長さの約 $5 \%$ である.ま た, 被験者が指定した位置を中心とする真の位 置の探索範囲は, 画像枠の面積の約 5\%の範囲 である。

（2）画像枠内の領域によって, 距離の基準の設定 が容易な領域では, 位置のずれが小さくなる傾 向が見られるが, 領域全体の場合の標準偏差值 で置き換えたとしても, 真の位置が検索範囲内 に存在する確率への影響は小さい.

したがって, 表示領域の影響については, 被 験者が指定した位置毎に検索の対象範囲を変化 させなくても, 領域全体から求めた想起の位置 ずれの標準偏差を用いてよい.

（3）位置を記憶する際の画面サイズと想起用の画 面サイズが等しくない場合, 記憶している位置 のずれの標準偏差はサイズ比と比例関係にな く, 画像枠の長さの $5 \%$ 以内に収まっている.

したがって, 絵葉書で見覚えのある画像を再 度モニタで検索するように, 記憶した元の画面 サイズと想起用の画面サイズが等しくない場合 でも, 画面サイズの違いの影響は考慮する必要 はない.

今回報告した実験結果は, 記憶保持時間の長さが短 期記憶の時間内であり, 人間が持つ位置関係の記憶の 精度についての基本的なものである。 また, 記憶の対 
象は 1 個の点であり, 日常的に行われる何らかの印象 を伴う対象物の配置の記憶とは, 記憶の精度が異なる 可能性がある.

今後, 位置の記憶の精度に影響すると考えられる 対象物体の形状, 大きさなど, 他の要因7)の影響およ びそれらの経時変化についても確認し, 検索時のユー ザインタフェース設計に扔けるパラメータの設定に反 映させる予定である.

日頃ご指導頂く羽鳥テレマティクスグループリーダ に感謝します。画像検索のユーザインタフェースに関 してご討論頂いた山田主幹研究員, マルチメディア端 末グループ野村担当主査およびテレマティクスグルー プの各位に感謝します。また, 被験者として実験にご 協力頂いた皆様に感謝します。

実験手順の図示のための原図の使用および変更に快 諾頂いた, ATR 視聴覚機構研究所の本郷仁志氏に深 謝致します。

\section{〔参 考 文 献〕}

1）浜野輝夫, 小倉健司：“作図プロセッサを用いた画像類似検 索手法の検討”, 信学技報, IE 87-88(1987)

2) S. K. Chang, C. W. Yan, D. C. Dimitroff, T. Arndt: "An Intelligent Image Database System", IEEE Trans. on Softw. Eng., SE-14, 5, pp. 681-688 (1988)

3）㗽場潔, 永田 尚, 松本陽一郎, 横山光男, 松下 温: “画 像検索におけるインタフェースの提案”, 情処学 $\mathrm{HI}$ 研報, 376 (July 1991)

4）西山晴彦, 饗場 潔, 横山光男, 松下 温：“略画作成による 画像検索システムのインタフェース”, 信学技報, SP 92-67, HC 92-44 (Sep. 1992)
5）坂 朋子, 小澤英昭, 小林直樹：“新聞記事検索における行動 の変化について”, 情処学ヒューマンインタフェース研資 457, 情処学情報メディア研資 8-7（Nov. 1991）

6）小野宏二, 笹野義二, 菅谷史昭, 宮里 勉：“位置情報を用い た画像検索手法”, 1991 年信学春季全大, D-434

7）島 則之, 高橋友一, 小林幸雄, 山下紘一：“ヒューマンイン タフェースにおける図形指示言語の評価実験”，テレビ学技 報, VVI 88-63 (1988)

8） R. L.クラッキー 著, 箱田裕司, 中溝幸夫 共訳：“記憶のし くみ I ", サイエンス社 (昭和 59 年)

9）桶渡涓二 編著, 樋渡涓二, 安田 稔, 大串健吾, 斉藤英昭 著：“視聴覚情報概論”, 昭晃堂（昭和 62 年）

10）田崎京二, 大山 正, 樋渡涓二 編：“視覚情報処理”, p. 362, 朝倉書店 (1976)

11）和田陽平, 大山 正, 今井省吾 編： “感覚・知覚心理学ハン ドブック”, 誠信書房（昭和 60 年）

12）石井淳一, 田村 博：“マウス操作における眼および手の時 間的協調について”, ヒューマンインタフェースシンポジウ ム論文集, 4, pp. 281-286（1988）

13）吉田 剛,田村 博：“マウス操作における眼球運動の解析”, ヒューマンインタフェースシンポジウム論文集, 4, pp. 287290 (1988)

14）飯田宗夫, 伴野 明：“頭部の動きを許容した注視点検出装 置と指示入力への応用”, 信学論 D-II, J74-D-II, 4. pp. 520527 (1991)

15）増山英太郎, 小林茂雄：“センソリー・エバリュエーション”, p. 104, 垣内出版 (1989)

16）J.P.ギルホード著, 秋重義治 監訳：“精神測定法”, p. 31, 培 風館 (1959)

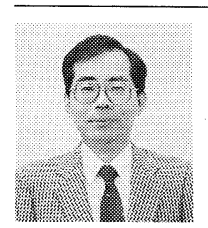

袈里若勉 昭和 53 年, 東京工業大学大 学院修士課程修了。同年, 国際電信電話 (株) に入社. 以来, 研究所に扔いて, 静止画像, 描画像の高能率符号化, VIDEOTEX 画面表 示変換, HI の研究に従事. 平成 5 年ょり, ATR 通信システム研究所知能処理研究室所 属. 工学博士. 正会員. 